In 1903 Filon was appointed lecturer in mathematics at University College, London, under the late Prof. M. J. M. Hill, and he became assistant professor of mathematics in 1906, a position in which he continued until 1912, when he succeeded Prof. Karl Pearson in the Goldsmid chair of applied mathematics and mechanics, tenable at University College. It was as a result of his teaching in the Department of Pure Mathematics that Filon produced his standard text-book on projective geometry, now in its fourth edition. He was elected a fellow of the Royal Society in 1910, and in 1935 a member of the Council and a vice-president of the Society, an honour which he much appreciated.

One of Filon's great interests was the University of London Officers' Training Corps, which, as BrevetColonel, he commanded from 1926 until 1932. He was already active in this connexion before the Great War, and he went on foreign service during 1914. He commanded the 2nd (Reserve) Battalion London Regiment from June 1915 until September 1916, after which his great technical abilities were more fitly utilized by his appointment to the technical staff of the Admiralty Air Service and of the Air Board.

After the War, Filon began to take an increased interest in the affairs of the University, as a result of which he was elected to the Senate in 1920, on which body he continued to serve until the time of his death. In all that had to do with University administration he showed the characteristic which, perhaps more than any other, distinguished his whole life-m thoroughness. Needless to say, his unswerving devotion to what he considered right, and his lack of that praiseworthy pliancy and useful obliquity which adorn some of our leading administrators, occasionally led him to oppose certain notable personalities, but, in spite of this, his services were so outstanding that he was elected vice-chancellor of the University in 1933-35, the period during which the foundation stone of the candid and considerable -may we say elephantine-University building was laid. In spite of his activities in University administration, Filon still found time to produce research of outstanding merit, and to help his students to produce original work.

Throughout his academic life, Filon held that the chief duty of any member of a university staff was to impart learning. He was an excellent teacher and never spared himself, whether the class was large or small, elementary or advanced. He was particularly careful about the organization of exercise classes. One of his enthusiasms was astronomy, and the existence of the University of London Observatory is very largely due to his efforts. He had a deep knowledge of the early history of astronomy, and gave an excellent course on the subject. As a lecturer he had a clear and compelling style, and was well able to adapt himself to a general audience, when he lectured, as he occasionally did, on a general topic.

Filon was a man of wide culture, and one who believed profoundly in the dignity of the academic profession. A congenial companion and a warm. hearted friend, he occasionally indulged in short bursts of irascibility, which, if they arose suddenly, as suddenly subsided. These outbreaks, so well known to his friends, were purely superficial disturbances, for fundamentally Filon was one of the most generous and kindly of men, who would put himself to great trouble even for those who had small claims on him. Nobody could be a pleasanter speaker or a better host. The large numbers which assembled at the memorial service held on January 14 were not brought together by feelings of formal courtesy to a distinguished colleague but came to salute the passing of a great spirit and a great friend.

E. N. DA C. ANdrade.

\section{Major E. E. Austen, D.S.O.}

THE name of E. E. Austen will live as that of a pioneer in the study of Diptera. Educated at Rugby and at the University of Heidelberg, he joined the staff of the British Museum in 1889 as the first curator to have sole and undivided charge of the collections of that order of insects. His first publication (January 1893) was upon a section of the family Syrphidæ (hover-flies), and his second (May 1895) upon the Estrid genus Cutiterebra (American botflies parasitic upon rodents). Quite early in his official career, however, he must have realized that the great amount of undescribed material and the necessity for intensive study made the Diptera as a whole too wide a field for research, and, as at that time the importance of Diptera as vectors of disease was beginning to be understood, he wisely decided to restrict his researches mainly to blood-sucking flies and certain other groups of medical or veterinary importance. It therefore came about that the revision of the Syrphidæ which he had planned was never continued, though he retained his interest in the CEstridæ, publishing several papers on the family so recently as $1933-34$.

Austen's interest in blood-sucking flies was doubtless cemented by a visit which he paid to Sierra Leone in 1899 in company with the late Sir Ronald (then Major) Ross, with the object of investigating the mosquitos of Freetown. This was the first expedition sent out by the Liverpool School of Tropical Medicine, and might well have led to his specializing on mosquitos, but he was called for service in the Boer War, and meanwhile the late F. V. Theobald was employed by the Museum to prepare a monograph of the Culicidæ. On his return from South Africa, Austen turned his attention to tsetse flies (Glossina) and horse-flies (Tabanidæ). His monograph of the genus Glossina (1903) was the first scientific revision of this group, later replaced (1911) by his more concise handbook. His numerous works on other blood-sucking flies include two separate volumes, "Illustrations of African Blood. sucking Flies" (1909) and "Illustrations of British Blood-sucking Flies" (1906), both long out of print, as well as many shorter papers descriptive mainly of African species. More widely known, perhaps, than any of his other publications was the Museum pamphlet which he compiled on "The House-fly as a Danger to Health", which had a very large sale and ran into several editions. 
Apart from the expedition to Sierra Leone men. tioned above, the only purely collecting trip which Austen made was in 1896, when he and the late F. O. Pickard Cambridge spent three months on the Amazon as naturalists on the cable ship Faraday. A greater opportunity for field work came to him during the Great War, when, after a period in France, in command of a company of the Artists' Rifles, he was transferred to the Egyptian Expeditionary Force for special duty in connexion with insect. born diseases. His work on mosquito and house. fly control earned him the D.S.O., and in spite of the arduous nature of this work he still found time and energy to make collections of other Diptera. Arrears of work, and later, official duties when he was appointed first deputy-keeper (1924) and then keeper (1927) of the Department of Entomology gave him little time for studying his Palestine collections. However, his retirement from the Museum staff in 1932 gave him more ample leisure and he turned with zest to the completion of a long-deferred labour of love and eventually (July 1937) produced a handsome volume on the Bombyliidæ of Palestine, which includes descriptions of the numerous species of this family collected by himself.

Austen's descriptive work, though sometimes criticized for a certain lack of conciseness in wording, embodied throughout three qualities upon which he always set a high value : accuracy, consistency and neatness. His neatness was exemplified in the wonderfully clear and firm handwriting, in which he took a just pride, and in the orderly arrangement of the collections under his charge. So precise indeed was this arrangement that visitors not infrequently remarked that the cabinet specimens were like well-trained regiments of soldiers on parade.

Although Austen's published work dealt almost exclusively with the groups of insects which were in his official charge, his interests were much wider. $\mathrm{He}$ preferred the Zoological Society to the Entomological Society on account of its wider outlook, and served on the publication committee of the former body. He was at one time vice-president of the Royal Society of Tropical Medicine and Hygiene, a member of the executive committees of the Imperial Institute of Entomology, the British Mosquito Control Institute, and the Society for the Preservation of the Fauna of the Empire. As a colleague he was loyal, purposeful, always anxious to increase the efficiency and prestige of his department, strongly resentful of injustice, and a strict disciplinarian. He was one of the small band to whom the present staff of the British Museum (Natural History) owes, almost entirely, the greatly improved conditions which the staff enjoys. Intensely patriotic, and with a very strong sense of the duty of a citizen, it is not surprising that he looked back with pride upon his service in the "C. I. V." and in the Great War, and that he took a keen and active interest in the local affairs of Northwood, where he had lived since 1913. Those who had the privilege of serving with him will always remember him, a man upright in body and mind, of sterling character, a manly man.
N. D. R. and F. W. E.

\section{Mr. J. L. Starkey}

ThE murder of Mr. J. L. Starkey, director of the Marston-Wellcome Archæological Expedition to the Near East, in Palestine on the evening of January 10, when he was on his way from his camp at Tell Duweir to Jerusalem to attend the opening ceremony of the new Palestine Archæological Museum on the following day, has deprived field archæology in the Near East of one of its most competent practitioners and exponents.

James Leslie Starkey was born on January 3, 1895, and received his training as a field archæologist under the British School of Archæology in Egypt. When in $1926 \mathrm{Sir}$ Flinders Petrie, owing to the restrictions imposed on archæological excavation in Egypt, transferred his activities to Palestine, Mr. Starkey accompanied him and became his right-hand man. A succession of operations on sites in the neighbourhood of Gaza brought to light important evidence bearing on the periods of the Egyptian occupation, the Hyksos and the early Bronze and Stone Ages of Palestine. More especially significant, perhaps, was the varied evidence which pointed to Palestine having been a centre or gathering point in international relations. This work led Starkey to the excavation of Tell Duweir.

The systematic excavation of Tell Duweir began in 1932. Mr. Starkey, convinced of the importance of this extensive site for Palestinian prehistory by the evidence of surface finds, and more especially by the abundance of potsherds it showed, approached Sir Charles Marston, for whom Prof. John Garstang was then excavating the site of Jericho, and persuaded him to undertake its investigation, at first in cooperation with Mr. H. D. Colt, and afterwards with Sir Henry Wellcome and Sir Robert Mond. The first season's systematic excavation went far to sub. stantiate, if indeed it did not quite fully confirm, his tentative conclusion that Tell Duweir, situated eighteen miles south-west of Jerusalem, rather than Tell el-Hesy, a site some ten miles away excavated many years before by Sir Flinders Petrie, was to be identified with the Biblical Lachish. The site was shown to have been in almost continuous occupation as a position of importance from the early Bronze Age down to the period of Persian occupation, while in the period of the Jewish kingdom when it was probably the centre of the defensive system of Palestine on this front, it had been sacked twice, inferentially by Sennacherib and Nebuchadnezzaron the second occasion burned. The identification with the Biblical Lachish was borne out later by the discovery here of the famous Lachish letters, the earliest known personal documents in Hebrew, and the earliest example of Hebrew writing. Even more important in the history of written records are the inscribed ewer and copper dagger, on which a primitive form of alphabetic script is held by experts to be closely akin to the Sinaitic script discovered by Sir Flinders Petrie, antedating considerably the earliest known Phœnician alphabetic scripts, which possibly may be derived from it.

This brief notice of Mr. Starkey's work cannot close without reference to one instance of his flair 